\title{
AN IMPROVED METHOD FOR MEASURING SOIL MICROBIAL ACTIVITY BY GAS PHASE FLOW INJECTION ANALYSIS ${ }^{(1)}$
}

\author{
Gregory Doran ${ }^{(2)}$ \& Alek Zander ${ }^{(2)}$
}

\begin{abstract}
The rate of carbon dioxide production is commonly used as a measure of microbial activity in the soil. The traditional method of $\mathrm{CO}_{2}$ determination involves trapping $\mathrm{CO}_{2}$ in an alkali solution and then determining $\mathrm{CO}_{2}$ concentration indirectly by titration of the remaining alkali in the solution. This method is still commonly employed in laboratories throughout the world due to its relative simplicity and the fact that it does not require expensive, specific equipment. However, there are several drawbacks: the method is timeconsuming, requires large amounts of chemicals and the consistency of results depends on the operator's skills. With this in mind, an improved method was developed to analyze $\mathrm{CO}_{2}$ captured in alkali traps, which is cheap and relatively simple, with a substantially shorter sample handling time and reproducibility equivalent to the traditional titration method. A comparison of the concentration values determined by gas phase flow injection analysis (GPFIA) and titration showed no significant difference $(p>0.05)$, but GPFIA has the advantage that only a tenth of the sample volume of the titration method is required. The GPFIA system does not require the purchase of new, costly equipment but the device was constructed from items commonly found in laboratories, with suggestions for alternative configurations for other detection units. Furthermore, GPFIA for $\mathrm{CO}_{2}$ analysis can be equally applied to samples obtained from either the headspace of microcosms or from a sampling chamber that allows $\mathrm{CO}_{2}$ to be released from alkali trapping solutions. The optimised GPFIA method was applied to analyse $\mathrm{CO}_{2}$ released from degrading hydrocarbons from a site contaminated by diesel spillage.
\end{abstract}

Index terms: $\mathrm{CO}_{2}$, microbial respiration, titration, infrared, FIA.

\footnotetext{
(1) Received for publication in February 17, 2011 and approved in November 30, 2011.

(2) EH Graham Centre for Agricultural Innovation, Charles Sturt University, School of Agricultural and Wine Sciences, Locked Bag 588, Wagga Wagga 2678, NSW, Australia. Email: gdoran@csu.edu.au
} 


\title{
RESUMO: OTIMIZAÇÃO DO MÉTODO PARA MEDIR ATIVIDADE MICROBIANA POR ANÁLISE POR INJEÇÃO EM FLUXO EM FASE GASOSA
}

\begin{abstract}
A taxa de produção de dióxido de Cé comumente utilizada como medida da atividade microbiana no solo. O método tradicional de determinação de $\mathrm{CO}_{2}$ envolve a captura do $\mathrm{CO}_{2}$ em solução alcalina e determinação indireta por meio da titulação da base remanescente em solução. Esse método é ainda comumente empregado em laboratórios por todo o mundo, devido à sua relativa simplicidade e ao fato de não ser dependente de equipamento caro $e$ específico. No entanto, o método possui várias desvantagens: é demorado, utiliza-se grande quantidade de reagentes químicos e a consistência dos resultados depende da habilidade de quem está analisando. Desse modo, foi desenvolvido um método otimizado de análise de $\mathrm{CO}_{2}$ capturado em soluções alcalinas, de baixo custo e relativamente simples, o qual fornece tempo de manuseio da amostra melhorado e com reprodutibilidade equivalente à do método de titulação tradicional. Uma comparação dos valores de concentração determinados por análise por injeção em fluxo em fase gasosa (GPFIA) e titulação mostrou que eles não foram significativamente diferentes ( $p>0,05)$, porém o GPFIA teve a vantagem de utilizar um décimo da quantidade de amostra do método da titulação. O sistema GPFIA não necessita de equipamentos novos e caros, tendo sido construido a partir de itens comumente encontrados em laboratórios, com sugestões para configurações alternativas para outras unidades de detecção. Além disso, o GPFIA para análise de $\mathrm{CO}_{2}$ pode ser igualmente aplicado em amostras obtidas tanto de "headspace" do microcosmo como de amostragens em câmaras que permitem o $\mathrm{CO}_{2}$ ser liberado da solução alcalina de captura. O método otimizado GPFIA foi aplicado para análise de $\mathrm{CO}_{2}$ liberado da degradação de hidrocarbonetos de um local contaminado por derramamento de diesel.
\end{abstract}

Termos de indexação: $\mathrm{CO}_{2}$, respiração microbiana, titulação, infravermelho, FIA.

\section{INTRODUCTION}

The biological oxidation to $\mathrm{CO}_{2}$ of natural and introduced carbon sources in soil is known as mineralisation, and results in the conversion of organic carbon to inorganic carbon (Zibilske 1976). The rate of $\mathrm{CO}_{2}$ production can therefore be used as a measure of microbial activity in terrestrial and aquatic oxic environments. However, measurement of analytes in the gas phase can be complicated by the need for specialised sampling techniques, sample storage devices and analytical instrumentation. When selecting a particular analytical approach, a researcher has to consider existing available equipment, funding for specialised analytical equipment and the envisaged future use should specific equipment be purchased.

Traditionally, $\mathrm{CO}_{2}$ evolution resulting from microbial activity was determined by trapping $\mathrm{CO}_{2}$ with alkali solutions, followed by the precipitation of carbonates with barium chloride and the titration of any remaining hydroxide with standardised acid (Stotzky, 1965). The principal advantage of this technique is that the analysis of the alkali solution may be deferred for short periods rather than requiring immediate analysis. However, this method has several drawbacks. The alkali trapping solution may be contaminated by atmospheric $\mathrm{CO}_{2}$ prior to its analysis, requiring both reagent and method blanks (Zibilske, 1976). To permit the selective titration of hydroxide ions, carbonates are precipitated using barium chloride thereby producing wastes containing heavy metals. Furthermore, the titration approach generally requires a large sample size, which can involve the use of the entire sample, thereby obviating the opportunity for re-analysis or replication within a given sample, should a particular result be questionable.

An extension of the alkali technique, the purgeand-trap (or dynamic) system, was reported more than 40 years ago (Stotzky, 1965). This adaptation involves purging the reaction chambers with $\mathrm{CO}_{2}$ free air, thereby allowing the $\mathrm{CO}_{2}$ generated in the microcosm to be more comprehensively trapped in alkali solution for quantification by titration. This technique has the advantage of replenishing $\mathrm{O}_{2}$ in the reaction chamber whilst removing $\mathrm{CO}_{2}$ immediately during periods of high soil microbial activity. Although this enhanced method still depends on the old titration method for the quantification of trapped $\mathrm{CO}_{2}$, it is still widely used. A survey of work published in Revista Brasileira de Ciência do Solo from 2004-2010 in which $\mathrm{CO}_{2}$ from microcosms was directly analysed, showed that approximately two thirds relied upon the use of alkali trapping and titration. Additionally, the 
last decade has seen numerous citations of the work published by Stotzky (1965) by various laboratories around the world, demonstrating the ongoing use of this fundamental technique (Ferreira et al., 2003, 2008; Scelza et al., 2007; Giacomini et al., 2008; Jacques et al., 2009; Suman et al., 2009; VinhalFreitas et al., 2010; Oliveira et al., 2011).

More recently, methods employing gas chromatography (GC) have been developed for $\mathrm{CO}_{2}$ analysis, whereby the air in soil microcosms is sampled directly without the reliance upon alkali trapping. These methods may employ a thermal conductivity detector (Rath et al., 1979; Chiaradia et al., 2009; Siqueira Neto et al., 2009) or the less sensitive electron capture detector (Thijsse, 1978) for $\mathrm{CO}_{2}$ detection. Whilst a simplified experimental setup is offered by headspace analysis, it does not prevent the accumulation of $\mathrm{CO}_{2}$ in the microcosm, nor does it replenish any $\mathrm{O}_{2}$ consumed. Additionally, GC relies upon specialised (and expensive) gas sampling ports, open bore chromatography columns and detectors, as well as requiring external calibration standards that can be difficult to reproduce reliably. Likewise, the use of commercially available dissolved organic carbon (DOC) analysers, mass spectrometers (Granström et al., 2002; Sherburne et al., 2005) and scintillation counters (Fulthorpe \& Schofield, 1999; Tuomela et al., 2002) may allow $\mathrm{CO}_{2}$ determination, but with purchase costs greatly exceeding that of even GC. Such instrumentation purchases are often beyond the reach of many laboratories, particularly when their use may only be for short-term or scoping projects.

Flow injection analysis (FIA) is a simple and cheap analytical technique in which a discrete volume of liquid standard or sample is injected into a flowing liquid carrier stream and passed through a detector. Whilst samples containing gas analytes may be analysed with specialised gas diffusion cells coupled with colorimetric detection methods (Hall \& Aller, 1992), FIA is not commonly undertaken using a gaseous mobile phase. Some reported methods do rely upon a gas mobile phase for the analysis of gases generated online, but none of these involved the direct injection of gaseous samples. For example, the analysis of ammonium and nitrate in water samples was achieved by converting each chemical species present to ammonia, and diffusing the ammonia so produced into a carrier gas stream through a gasliquid separator (Haghighi \& Kurd, 2004). Likewise, nitrate and nitrite were analysed in water samples by conversion to $\mathrm{NO}_{\mathrm{x}}$ gases (Kanda \& Taira, 2003).

The continued relevance of the method reported by Stotzky (1965) is likely to be the result of several factors, but is primarily due to its simplicity and low cost compared to the considerable cost of purchasing advanced instrumentation. The work presented here describes a method for gas-phase flow injection analysis (GPFIA) utilising infrared $\mathrm{CO}_{2}$ detection, coupled with the traditional purgeand-trap system (dynamic) system that replenishes microbially consumed $\mathrm{O}_{2}$ and removes $\mathrm{CO}_{2}$ using alkali traps. $\mathrm{CO}_{2}$ is released from the traps by the addition of a strong acid in a specially developed sampling chamber, with the gas evolved being collected in a syringe for subsequent injection into the GPFIA system. The instrumentation can be easily assembled from materials present in many laboratories and allows the user to perform cheap, simple and reliable analyses of $\mathrm{CO}_{2}$, and permits multiple injections of the same sample or standard, if so required.

\section{MATERIALS AND METHODS}

\section{$\mathrm{CO}_{2}$ purge-and-trap apparatus}

A purge-and-trap (or dynamic incubation) system was constructed, based upon the apparatus previously proposed (Zibilske, 1976). Laboratory compressed air was passed through a series of traps consisting of glass test tubes $(200 \times 26 \mathrm{~mm})$ fitted with rubber stoppers (Figure 1). A plastic disposable pipette $(1 \mathrm{~mL})$ was inserted through one of two holes in each stopper and a disposable syringe needle was fitted to the end of the pipette, ensuring the tip of this needle was near the base of the test tube. A short length of plastic disposable

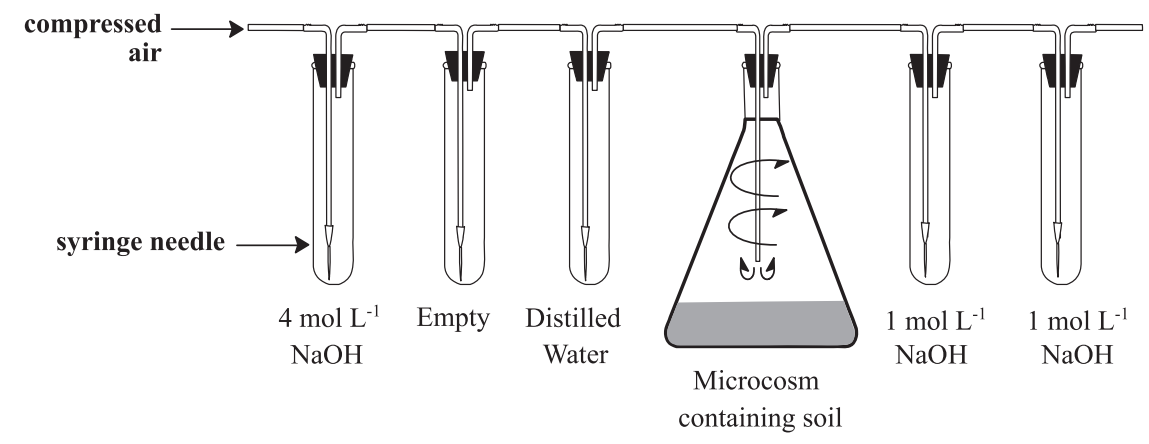

Figure 1. Purge-and-trap apparatus used to collect $\mathrm{CO}_{2}$ produced by soil microbes. 
pipette $(1 \mathrm{~mL})$ was inserted through the second hole in the stopper. The tubes were connected in series with a microcosm chamber. The air passed through 3 traps before entering the microcosm chamber: trap 1 contained $\mathrm{NaOH}\left(4 \mathrm{~mol} \mathrm{~L}^{-1}\right.$, $50 \mathrm{~mL}$ ) to remove ambient $\mathrm{CO}_{2}$; trap 2 was empty and acted as a moisture trap after trap 1; trap 3 contained deionised water (from which all $\mathrm{CO}_{2}$ had been removed by sparging with $\mathrm{N}$ for $30 \mathrm{~min}$ ) and humidified the air stream, thereby reducing evaporation from the microcosm chamber. The air then passed through the microcosm consisting of a conical flask $(250 \mathrm{~mL})$ containing soil $(100 \mathrm{~g})$. After the microcosm, the air flowed through two further consecutive alkali traps containing $\mathrm{NaOH}(50 \mathrm{~mL}$, $1 \mathrm{~mol} \mathrm{~L}^{-1}$ ) before being vented to the atmosphere. These last two alkali traps were removed weekly for $\mathrm{CO}_{2}$ analysis and immediately replenished with fresh $\mathrm{NaOH}$, while the $\mathrm{CO}_{2}$ scrubber trap containing the $4 \mathrm{~mol} \mathrm{~L}^{-1} \mathrm{NaOH}$ was replaced every 3-4 weeks.

\section{$\mathrm{CO}_{2}$ sampling chamber}

A sampling chamber was constructed from an Erlenmeyer flask $(250 \mathrm{~mL}$ ) connected to ultrapure N (99.99 \%) via the flask side arm (Figure 2). A length of glass tubing was inserted through a rubber stopper in the top of the flask, extending to within $15 \mathrm{~mm}$ of the base of the flask. A short length of silicone tubing attached to the exterior end of the glass tubing permitted the attachment of a syringe (60 $\mathrm{mL})$ for gas sampling.

\section{Calibration and sample analysis}

Before initiating the sample analysis proper, the GPFIA method was calibrated employing the same procedure as that used later for sample analysis. Firstly, the sampling chamber was purged with N (2 min, $2 \mathrm{~L} \mathrm{~min}^{-1}$ ), after which time the $\mathrm{N}$ flow was stopped and a syringe $(60 \mathrm{~mL})$ attached to the adaptor in the top of the sampling chamber (Figure 2). The stopper was then removed from the chamber and an aliquot of standard was injected into the base of the

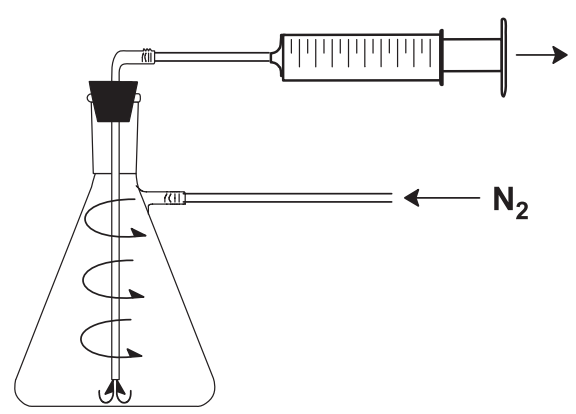

Figure 2. $\mathrm{CO}_{2}$ sampling chamber used to regenerate $\mathrm{CO}_{2}$ gas from alkali traps for quantification. sample chamber (flask), ensuring the glass tube was not contaminated, thereby minimising carryover to the next sample. An aliquot of $\mathrm{HCl}(1.5 \mathrm{~mL}$, $6 \mathrm{~mol} \mathrm{~L}^{-1}$ ) was added to the standard in the chamber, the stopper immediately reinserted and the flask swirled to ensure a complete reaction. After stirring was completed, a slight $\mathrm{N}$ flow $\left(\sim 200 \mathrm{~mL} \mathrm{~min}^{-1}\right)$ was recommenced, thereby filling the syringe at the top of the sampling chamber with gas from the base of the chamber (Figure 2). Once the syringe was full (the plunger was fully extended), the syringe was disconnected from the sampling chamber and attached to the injection port of the gas sampling valve on the FIA system. The sampling chamber was then rinsed with de-gassed, instrument grade water prior to re-purging and reuse.

For the calibration procedure, a single carbonate standard $\left(20 \mathrm{mmol} \mathrm{L}^{-1}\right)$ was prepared by dissolving sodium carbonate in instrument grade water $(100 \mathrm{~mL})$ that had been purged with $\mathrm{N}(30 \mathrm{~min})$ to remove any dissolved $\mathrm{CO}_{2}$. Aliquots $(0.5-3.0 \mathrm{~mL})$ of this standard were analysed for the preparation of a calibration curve (Figure 3). For sample analysis, each pair of $\mathrm{CO}_{2}$ sampling traps were removed from the microcosm apparatus, the contents of the traps combined and aliquots of this combined sample analysed in relation to the standards. The sample aliquot size was in the range of $0.5-5.0 \mathrm{~mL}$, the actual size depending on the anticipated $\mathrm{CO}_{2}$ concentration present.

\section{Chamber flushing efficacy}

The efficacy of the $\mathrm{N}$ flushing step in the $\mathrm{CO}_{2}$ sampling chamber was confirmed by injecting ammonia solution $\left(1 \mathrm{~mL}, 2 \mathrm{~mol} \mathrm{~L}^{-1}\right)$ into the chamber followed by $\mathrm{HCl}\left(1.5 \mathrm{~mL}, 6 \mathrm{~mol} \mathrm{~L}^{-1}\right)$. The resulting chemical reaction produced ultrafine $\mathrm{NH}_{4} \mathrm{Cl}$ particles that filled the chamber as smoke. Subsequent flushing of the chamber with $\mathrm{N}$ cleared the chamber of smoke within $10 \mathrm{~s}$ and visually demonstrated the gas flow pattern (Figure 2). To ensure that even trace levels of $\mathrm{NH}_{4} \mathrm{Cl}$ smoke (or $\mathrm{CO}_{2}$ during actual sampling) were flushed, the chamber was purged for a total of $1 \mathrm{~min}$. Furthermore, injections which vacated chamber after flushing during the sample analysis cycle indicated that no detectible levels of $\mathrm{CO}_{2}$ remained in the sampling chamber, confirming that the potential for carryover between samples was negligible.

\section{Gas phase flow injection analysis}

A GPFIA system was constructed from a gas sampling valve from a Pye-Unicam gas chromatograph, which was fitted with a larger sampling loop (4 mL). The inlet side was connected to ultrapure $\mathrm{N}(99.99 \%)$ for the mobile phase 


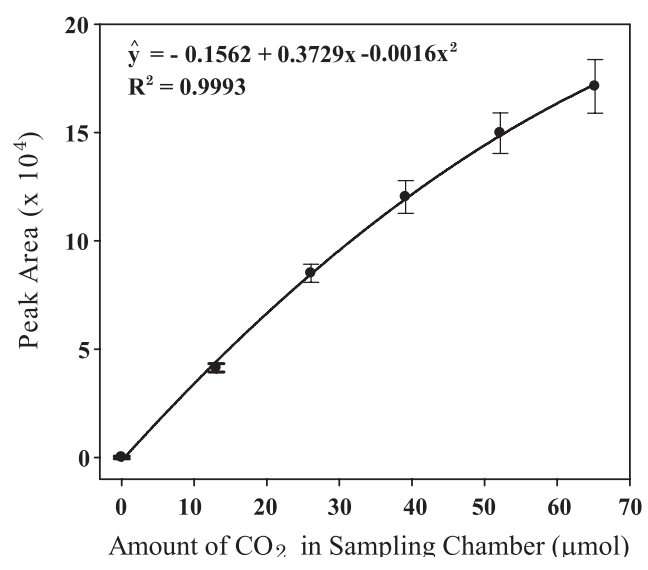

Figure 3. Calibration curve for $\mathrm{CO}_{2}$ analysis by GPFIA (mean $\pm \mathrm{SD}, \mathrm{n}=4)$.

$(200 \mathrm{~mL} \mathrm{~min}-1)$. The injection valve was connected to a tin/copper filter (to remove acidic vapours) and then to an infrared $\mathrm{CO}_{2}$ gas analyser (California Analytical Instruments, Model 3300) salvaged from a decommissioned total organic $\mathrm{C}$ analyser. The detector collected light at $2.7,4.4$, and $14.1 \mathrm{~mm}$ simultaneously, and while operable over two ranges (0-500 and 0-2500 ppm), was used for the current purpose only in the less sensitive range. The 0-1 volt signal from the IR detector was logged using Star Chromatography v6.2 (Varian, Australia) to allow peak integration. For sample analysis, the sample loop (with the gas sampling valve in the "load" position) was flushed with the contents of a syringe that had been filled from the $\mathrm{CO}_{2}$ sampling chamber (see above). The injection valve was then switched from the "load" to the "inject" position for $5 \mathrm{~s}$ and subsequently returned to the "load" position. $\mathrm{A} \mathrm{CO}_{2}$ peak was recorded within $10 \mathrm{~s}$ of the sample injection.

\section{Titrations}

The concentration of $\mathrm{CO}_{2}$ in each pair of alkali traps was determined indirectly using traditional titration methodology with $\mathrm{HCl}$ to compare with the results obtained using GPFIA. Aliquots of alkali $(10 \mathrm{~mL})$ were added to Erlenmeyer flasks and treated with $\mathrm{BaCl}_{2}\left(3 \mathrm{~mL}, 3 \mathrm{~mol} \mathrm{~L}{ }^{-1}\right)$ to precipitate carbonates. Several drops of phenolphthalein indicator were added, and the solution titrated against standardised $\mathrm{HCl}\left(0.5 \mathrm{~mol} \mathrm{~L}^{-1}\right)$.

\section{GPFIA Optimisation and Interferences}

The effect of $\mathrm{N}$ flow rate through the GP-FIA system on peak area, width and on reproducibility as well as analysis time, was investigated. Flow rates were varied between 100 and $500 \mathrm{~mL} \mathrm{~min}^{-1}$ using quadruplicate injections of $\mathrm{CO}_{2}$ derived from acidification of aliquots of sodium carbonate standard (1 mL, $\left.20 \mathrm{mmol} \mathrm{L}^{-1}\right)$.
Interferences that normally plague the traditional titration method of $\mathrm{CO}_{2}$ analysis were tested to determine the level of interference on the new GP-FIA method. Diesel $(10 \mathrm{~mL})$ and/or ammonia solution $\left(100 \mathrm{~mL}, 2 \mathrm{~mol} \mathrm{~L}^{-1}\right)$ were added to the $\mathrm{CO}_{2}$ sampling chamber aside from an aliquot of sodium carbonate standard $\left(1 \mathrm{~mL}, 20 \mathrm{mmol} \mathrm{L}^{-1}\right)$ and the evolution of $\mathrm{CO}_{2}$ determined as previously described.

\section{Determination of Microbial Activity using GPFIA}

To demonstrate the usefulness of the GPFIA system, soil (100 g) from a diesel-contaminated site was added to the microcosm chamber in several dynamic incubation systems. Soils were amended with sheep manure (5 g), sheep manure/urea (5 g/60 mg) or sheep manure/glucose combinations $(5 \mathrm{~g} / 500 \mathrm{mg})$. Additionally, uncontaminated soil $(100 \mathrm{~g})$ collected immediately adjacent to the contaminated site was added to additional chambers as a control. $\mathrm{CO}_{2}$-free air was passed through the dynamic incubation systems to purge any $\mathrm{CO}_{2}$ produced and trap it in in the dual $\mathrm{NaOH}$ traps. Incubation of microcosms lasted for a total of 65 days with traps being removed weekly for $\mathrm{CO}_{2}$ analysis by GPFIA.

\section{RESULTS AND DISCUSSION}

In the development of any improved method, it is essential to investigate how various operating parameters affect the sensitivity, accuracy and repeatability of sample measurement. In addition, since the major aim of our present method development was to reduce reliance upon operator skill while increasing sample throughput, it was important that the optimised operating conditions did not compromise these facets of the final operation. To this end, the following aspects of the gas phase flow injection analysis (GPFIA) method were investigated: GPFIA carrier gas flow rate; $\mathrm{N}$ purge of the $\mathrm{CO}_{2}$ sampling chamber; and the potential for other species (namely ammonia and diesel) to interfere with the analysis.

\section{Optimisation of GPFIA}

Optimal conditions for GPFIA were established by varying the flow rate of the $\mathrm{N}$ carrier gas through the GPFIA system in an attempt to maintain high sample throughput, adequate sensitivity, and repeatability of standard and sample injections. FIA generally results in a loss of sensitivity as the sample slug passes through the detector before the detector has sufficient time to respond fully. As carrier flow decreases, the residence time of the sample in the 
detector increases, allowing the detector more time to respond, resulting in a larger peak area (Figure 4). However, as the flow rate decreased the magnitude of the error increased - an effect which is believed to be due to greater diffusion of the sample in the carrier gas. A search of recent literature for FIA in which the carrier was a gas (eg N) indicated that no work has been published in this area as gas in gas analysis is not usually employed, and hence the phenomenon is not commonly observed.

Figure 4 shows sample throughput of the GPFIA system. While slower flow rates resulted in a better detector response, it came at the cost of both reproducibility (and hence the reliability of the technique) as well as sample throughput. Optimal efficiency for sample throughput was obtained at a flow rate of $300 \mathrm{~mL} \mathrm{~min}^{-1}$. However, $200 \mathrm{~mL} \mathrm{m^{-1 }}{ }^{-1}$ was chosen as the optimal carrier flow rate for experimental work as it provided a $50 \%$ increase in detector response for a $10 \%$ loss in sample throughput, as well as adequate reproducibility when compared to a flow rate of $300 \mathrm{~mL} \mathrm{~min}{ }^{-1}$. Figure 5 shows a typical sample trace, demonstrating sample throughput of one sample approximately every two minutes, as well as illustrating the reproducibility of the technique.

Originally, a glass jar sealed with plastic film was used as a sampling chamber. However, ambient air containing $\mathrm{CO}_{2}$ was drawn into the chamber during sampling thereby contaminating the $\mathrm{CO}_{2}$ generated from samples and standards. To overcome this problem, the sampling chamber shown in figure 2 was developed and provided two distinct advantages over its predecessor; quick rinsing with instrument grade water between samples allowed reuse of the chamber, and permanent connection to a $\mathrm{N}$ source allowed the chamber headspace to be flushed of residual $\mathrm{CO}_{2}$ from the previous sample to eliminate carryover.

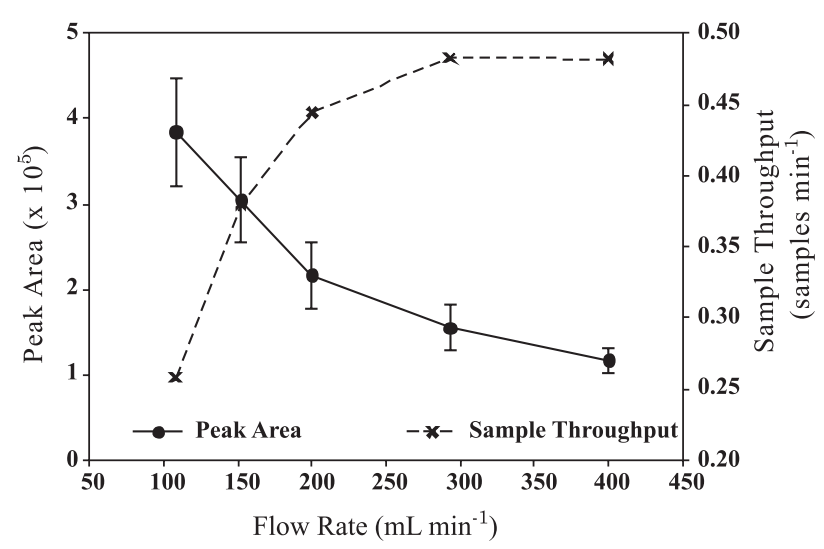

Figure 4. The effect of nitrogen carrier flow rate on peak area and peak width at half height (mean $\pm \mathrm{SD}, \mathrm{n}=4$ ).

\section{Potential Interferences for GPFIA}

Ammonia and hydrocarbons in soils have been identified as potentially interfering with titrimetric determination of $\mathrm{CO}_{2}$ (Zibilske, 1976). Consequently, their effect on $\mathrm{CO}_{2}$ determination by GPFIA was investigated. Ammonia and/or diesel solutions were applied to the sampling chamber prior to the addition of the sodium carbonate standard and hydrochloric acid, and the determined concentrations compared to the concentration when only sodium carbonate and hydrochloric acid were added. As can be seen in table 1, the addition of ammonia and diesel to the sampling chamber prior to the addition of the sodium carbonate standard and hydrochloric acid, does not appear to interfere with $\mathrm{CO}_{2}$ determination. The concentration of $\mathrm{CO}_{2}$ generated from spiked solutions did not differ from the concentration of $\mathrm{CO}_{2}$ generated from a sodium carbonate solution alone $(\mathrm{p}>0.05)$.

Table 1. Interference of ammonia and hydrocarbons on $\mathrm{CO}_{2}$ determination by GPFIA (Mean $\pm \mathrm{SD}$, $\mathrm{n}=4$ )

\begin{tabular}{lc}
\hline \multicolumn{1}{c}{ Solution } & $\mathbf{C O}_{\mathbf{2}}$ Concentration \\
\hline & mmol L-1 \\
& $18.8 \pm 1.1$ \\
$\mathrm{Na}_{2} \mathrm{CO}_{3}$ only & $20.1 \pm 1.5$ \\
$\mathrm{Na}_{2} \mathrm{CO}_{3}+$ ammonia & $17.6 \pm 1.7$ \\
$\mathrm{Na}_{2} \mathrm{CO}_{3}+$ diesel & $18.4 \pm 1.2$ \\
$\mathrm{Na}_{2} \mathrm{CO}_{3}+$ ammonia + diesel & \\
\hline
\end{tabular}

Initial injections with the GPFIA system resulted in an increase in the baseline after the $\mathrm{CO}_{2}$ slug passed through the detector when the injection valve was left in the "Inject" position for the duration of the injection, making integration of the peak area difficult (Figure 6). This effect was likely due to the increased path length through which the carrier gas must pass when the injection valve is left in the "Inject" position. The problem was eliminated by switching the injection valve to the "Inject" position for only $5 \mathrm{~s}$, and then immediately returning it to the "Load" position. Subsequent tests showed that using this type of pulsed injection technique to introduce the $\mathrm{CO}_{2}$ sample/standard slug into the carrier stream caused the detector signal to return to the same baseline level as that existing prior to the onset of the $\mathrm{CO}_{2}$ peak (Figure 5).

\section{Comparison of GPFIA and Titration Methods}

Four different alkali samples collected from the $\mathrm{CO}_{2}$ Purge-and-trap apparatus were analysed for $\mathrm{CO}_{2}$ via the new GPFIA method using quadruplicate 


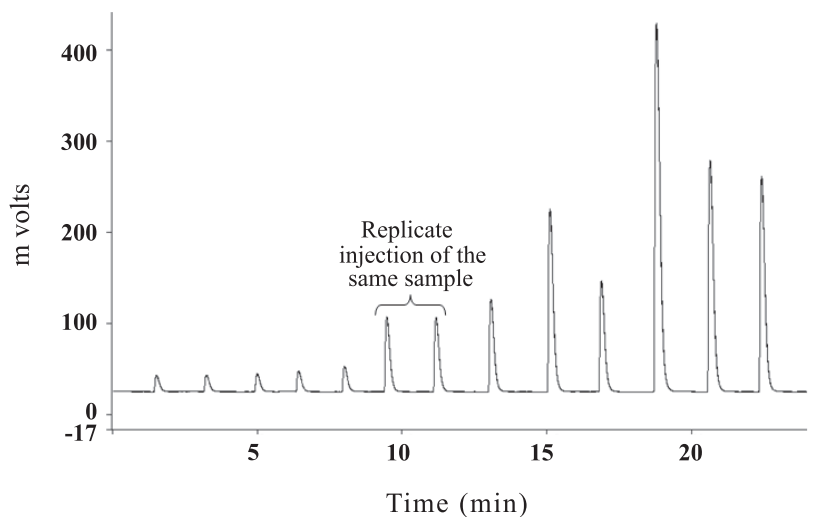

Figure 5. Trace of samples illustrating replication and rapid turnaround of samples with each peak, representing an individual sample injection.

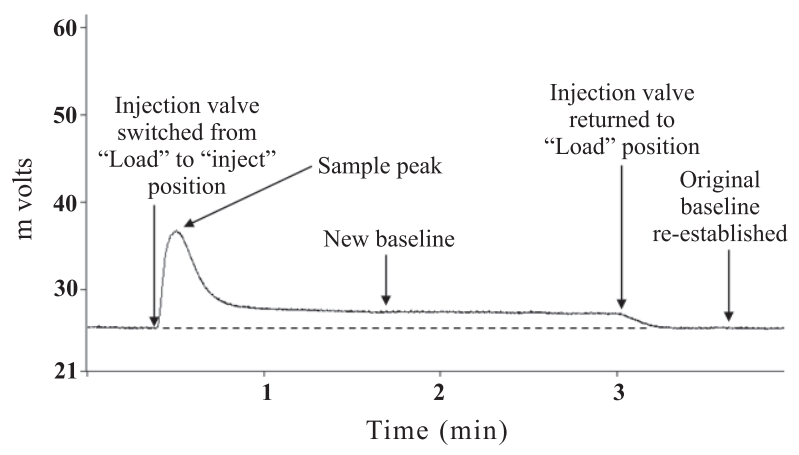

Figure 6. Trace showing the effect of the valve position on baseline detector response.

injections. The results obtained were compared to those determined using a traditional acidbase titration method (Table 2). From an initial inspection of the results, it appears that for both methods there are consistent differences between the 1 and $2 \mathrm{~mL}$ sample volumes: for the $2 \mathrm{~mL}$ sample volume GPFIA yielded consistently higher values and the titration method consistently lower values. However, these differences were not significant $(\mathrm{p}>0.05)$.
The relative magnitude of the error was greater when using GPFIA with a $2 \mathrm{~mL}$ sample volume compared to those when using a $1 \mathrm{~mL}$ sample volume, and is believed to be due to deviations from linearity of light absorption at higher $\mathrm{CO}_{2}$ concentrations. This belief is supported by the fact that calibration graphs tended to be slightly curvilinear. Conversely, the error was lower when the larger $2 \mathrm{~mL}$ volume was used for titrations. This outcome is to be reasonably expected, since larger titres mean that the small variations between replicate titrations became proportionally smaller when $1 \mathrm{~mL}(0.5 \mathrm{~mL})$ sample volumes were used. Likewise, there was no difference between concentration values determined by GPFIA and titration for each sample ( $p>0.05)$.

The analysis of $\mathrm{CO}_{2}$ from a trial involving the microbial degradation of hydrocarbons in diesel-contaminated soil is presented by way of an illustration of the application of the optimised GPFIA methodology (Figure 7). The $\mathrm{CO}_{2}$ production rate in contaminated soil was greater than in uncontaminated soil, showing the use of the hydrocarbons as a substrate by the microbial population. The degradation of the diesel hydrocarbons for the production of this $\mathrm{CO}_{2}$ is further supported by gas chromatography mass spectrometer analysis (data not shown). The addition of sheep manure, as a source of microbial organisms and additional nutrients, accelerated $\mathrm{CO}_{2}$ production but this production was not further enhanced by the addition of urea with the manure. The addition of glucose, as a primary substrate in the case of diesel degradation by cometabolism, along with glucose shows increased $\mathrm{CO}_{2}$ production $(p<0.05)$ over the addition of manure alone. These results demonstrate the usefulness of the GPFIA method for determining differences in $\mathrm{CO}_{2}$ production from microbial metabolic cultures. Analysis of quadruplicate samples for the five treatments by GPFIA took approximately 1 hour compared to more than 5 hours by traditional acid/ base titration. Additionally, all waste produced by GPFIA was aqueous for simple disposal compared to barium waste produced by the titration method.

Table 2. Comparison of $\mathrm{CO}_{2}$ analyser and titration results (Mean $\left.\pm \mathrm{SD}, \mathrm{n}=4\right)$

\begin{tabular}{|c|c|c|c|c|c|}
\hline \multirow{2}{*}{ Analysis method } & \multirow{2}{*}{ Sample volume } & \multicolumn{4}{|c|}{$\mathrm{CO}_{2}$ Concentration } \\
\hline & & Sample 1 & Sample 2 & Sample 3 & Sample 4 \\
\hline & $\mathrm{mL}$ & \multicolumn{4}{|c|}{$\mathrm{mmol} \mathrm{L}^{-1}$} \\
\hline GPFIA & $\begin{array}{l}1.00 \\
2.00\end{array}$ & $\begin{array}{l}122 \pm 3 \\
124 \pm 5\end{array}$ & $\begin{array}{l}48 \pm 1 \\
50 \pm 3\end{array}$ & $\begin{array}{l}178 \pm 3 \\
186 \pm 5\end{array}$ & $\begin{array}{l}105 \pm 1 \\
106 \pm 5\end{array}$ \\
\hline Titration & $\begin{array}{l}1.00 \\
2.00\end{array}$ & $\begin{array}{l}128 \pm 4 \\
125 \pm 2\end{array}$ & $\begin{array}{l}47 \pm 3 \\
46 \pm 3\end{array}$ & $\begin{array}{l}186 \pm 4 \\
184 \pm 4\end{array}$ & $\begin{array}{l}102 \pm 4 \\
100 \pm 2\end{array}$ \\
\hline
\end{tabular}




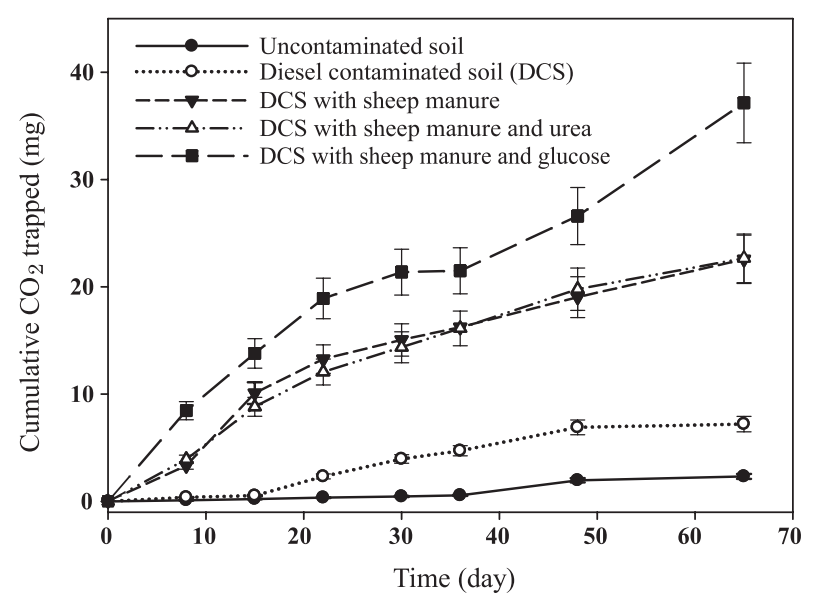

Figure 7. Trace showing the effect of the valve position on baseline detector response.

Any new analytical technique must offer advantages over an existing technique to ensure its adoption. The technique described in this work is cheap, fast, simple and reproducible, and is also less susceptible to operator variability than the more traditional titration methodology. This technique can be used to sample and analyse $\mathrm{CO}_{2}$ either directly from the headspace of microcosms or from alkali traps by employing the sampling chamber with the small sample volume required readily permitting multiple injections per sampling time. Samples with high concentrations do not require dilution since smaller volumes of sample can be injected into the sampling chamber without variation in the determined value $(p>0.05)$. In addition, analysis costs are reduced due to decreased chemical consumption and sample throughput is faster than by titration methods. Since the ratelimiting step in the process is sample collection, sample throughput could be increased further by using two separate, identical sampling chambers to minimise downtime between injections.

Importantly, the new technique eliminates two common interferences (ammonia and hydrocarbons) that require modification of the $\mathrm{CO}_{2}$ trapping apparatus to minimise their impact when using an acid-base titration method (Zibilske, 1976). This occurs specifically because the new technique measures $\mathrm{CO}_{2}$ directly, rather than indirectly, as is the case with acid-base titration methods. The typical purchase cost of a $\mathrm{CO}_{2}$ flow analyser is modest, compared to tens of thousands of dollars for TOC analysers and GCs. While a dedicated $\mathrm{CO}_{2}$ analyser was used in the work reported here, initial work was conducted using a standard infrared spectrophotometer with a flow cell which is commonplace in instrumental laboratories, allowing the instrumentation described in this manuscript to be replicated more readily.

\section{FINAL CONSIDERATIONS AND CONCLUSIONS}

The work presented demonstrates an improved method for the measurement of $\mathrm{CO}_{2}$ produced by microbial respiration in soil microcosms that does not rely upon the purchase of expensive, dedicated instrumentation. Gas-phase flow injection analysis (GPFIA) has been shown to provide much faster sample turnaround than the more traditional titration method with comparable precision: GPFIA shows a standard deviation of $3.1 \pm 1.7 \%$ compared to $3.5 \pm 2.0 \%$ for titration. This improved method has the added benefit of obviating the potential for ammonia and hydrocarbons present in the sample to interfere with the $\mathrm{CO}_{2}$ analysis, as is the case with titrimetric determination of $\mathrm{CO}_{2}$. Our analytical instrumentation was constructed from equipment commonly available in research laboratories and permitted a scoping study in soil microbial activity to be undertaken without committing significant funds to the purchase of new equipment, with a rate of sample analysis more than five times faster than the traditional acid/base titration method.

\section{ACKNOWLEDGEMENTS}

The authors would like to thank the Faculty of Science, Charles Sturt University for funding this work.

\section{LITERATURE CITED}

CHIARADIA, J.J.; CHIBA, M.K.; ANDRADE, C.A.D.; CARMO, J.B.D.; OLIVEIRA, C.D. \& LAVORENTI, A. $\mathrm{CO}_{2}, \mathrm{CH}_{4}$ and $\mathrm{N}_{2} \mathrm{O}$ fluxes in an Ultisol treated with sewage sludge and cultivated with castor bean. R. Bras. Ci. Solo, 33:18631870, 2009.

FERREIRA, A.D.; OLIVEIRA, R.S.; SANTOS, M.A. \& BORGES, E.N. Respiratory activity of soil microbiota and glucose content in response to phosphorus addition in Cerrado soilBrazil. R. Bras. Ci. Solo, 32:1891-1897, 2008.

FERrEirA, A.S.; CAMARGO, F.A.O.; TEDESCO, M.J. \& BISSANI, C.A. Effects of tannery and coal mining residues on chemical and biological soil properties and on corn and soybean yields. R. Bras. Ci. Solo, 27:755-763, 2003.

FULTHORPE, R.R. \& SCHOFIELD, L.N. A comparison of the ability of forest and agricultural soils to mineralize chlorinated aromatic compounds. Biodegradation, 10:235244, 1999.

GIACOMINI, S.J.; AITA, C.; MIOLA, E.C.C. \& RECOUS, S. Carbon mineralization of straw and pig manure with and without incorporation of soil. R. Bras. Ci. Solo, 32:26612668, 2008. 
GRANSTRÖM, T.; LINDBERG, P.; NUMMELA, J.; JOKELA, J. \& LEISOLA, M. Biodegradation of VOCs from printing press air by an on-site pilot plant bioscrubber and laboratory scale continuous yeast cultures. Biodegradation, 13:155$162,2002$.

HAGHIGHI, B. \& KURD, S.F. Sequential flow injection analysis of ammonium and nitrate using gas phase molecular absorption spectrometry. Talanta, 64:688-694, 2004.

HALL, P.O.J. \& ALLER, R.C. Rapid, small-volume, flow injection analysis for $\mathrm{CO}_{2}$ and $\mathrm{NH}_{4}{ }^{+}$in marine and freshwaters. Limnol. Oceanogr., 37:1113-1119, 1992.

JACQUES, R.J.S.; OKEKE, B.C.; BENTO, F.M.; PERALBA, M.C.R. \& CAMARGO, F.A.O. Improved enrichment and isolation of polycyclic aromatic hydrocarbons (pah)-degrading microorganisms in soil using anthracene as a model PAH. Curr. Microbiol., 58:628-634, 2009.

KANDA, Y. \& TAIRA, M. Flow-injection analysis method for the determination of nitrite and nitrate in natural water samples using a chemiluminescence $\mathrm{NO}_{\mathrm{x}}$ monitor. Anal. Sci., 19:695-699, 2003.

OLIVEIRA, N.M.; BENTO, F.M.; CAMARGO, F.A.O.; KNORST, A.J.; DOS SANTOS, A.L.; PIZZOLATO, T.M. \& PERALBA, M.D.R. Biodegradation of commercial gasoline (24\% ethanol added) in liquid medium by microorganisms isolated from a landfarming site. J. Environ. Sci. Health Part A-Toxic/Hazard. Subst. Environ. Eng., 46:86-96, 2011.

RATH, H.J.; SCHMIDT, D. \& WIMMER, J. Determination of traces of carbon dioxide in hydrogen chloride by gas chromatography. Chromatographia, 12:567, 1979.

SCELZA, R.; RAO, M.A. \& GIANFREDA, L. Effects of compost and of bacterial cells on the decontamination and the chemical and biological properties of an agricultural soil artificially contaminated with phenanthrene. Soil Biol. Biochem., 39:1303-1317, 2007.
SHERBURNE, L.; SHROUT, J. \& ALVAREZ, P. Hexahydro-1,3,5-trinitro-1,3,5-triazine (RDX) degradation by Acetobacterium paludosum. Biodegradation, 16:539-547, 2005.

SIQUEIRA NETO, M.; PICCOLO, M.D.C.; FEIGL, B.J.; VENZKE FILHO, S.D.P.; CERRI, C.E.P. \& CERRI, C.C. Crop rotation under no-tillage in Tibagi (Paraná State, Brazil). II - $\mathrm{CO}_{2}$ and $\mathrm{N}_{2} \mathrm{O}$ emissions. R. Bras. Ci. Solo, 33:1023-1029, 2009.

STOTZKY, L.M. Chemical and microbiological properties. In: BLACK, C.A.E.; WHITE, J.L.; ENSMINGER, L.E. \& CLARKE, F.E., ed. Methods of soil analysis. Madison, Soil Science Society of America, 1965. v.2. p.1550-1572.

SUMAN, A.; SINGH, K.P.; SINGH, P. \& YADAV, R.L. Carbon input, loss and storage in sub-tropical Indian Inceptisol under multi-ratooning sugarcane. Soil Tillage Res., 104:221$226,2009$.

THIJSSE, T.R. Gas chromatographic measurement of nitrous oxide and carbon dioxide in air using electron capture detection. Atmos. Environ., 12:2001-2003, 1978.

TUOMELA, M.; HATAKKA, A.; KARJOMAA, S. \& ITÄVAARA, M. Priming effect as determined by adding ${ }^{14} \mathrm{C}$-glucose to modified controlled composting test. Biodegradation, 13:131-140, 2002.

VINHAL-FREITAS, I.C.; WANGEN, D.R.B.; FERREIRA, A.D.; CORREA, G.F. \& WENDLING, B. Microbial and enzymatic activity in soil after organic composting. R. Bras. Ci. Solo, 34:757-764, 2010.

ZIBILSKE, L.M. Microbiological and biochemical properties. In: WEAVER, R.W.A.; S.; BOTTOMLEY, P.; BEZDICEK, D.; SMITH, S.;TABATABAI, A. \& WOLLUM, A., ed. 'Methods of soil analysis. Madison, Soil Science Society of America, 1976. v.2. p.835-863. 
